DEPARTMENT OF THE INTERIOR

U.S. GEOLOGICAL SURVEY

\title{
THERMAL MATURITY OF HYDROCARBON-BEARING FORMATIONS IN SOUTHWESTERN WYOMING AND NORTHWESTERN COLORADO
}

\author{
By E. A. Merewether, K. B. Krystinik, \\ and M. J. Pawlewicz
}

Prepared in cooperation with the U.S. DEPARTMENT OF ENERGY 